\title{
Immunovirological discordance among female sex workers who start antiretroviral therapy in Burkina Faso
}

\author{
Wilfried Wenceslas Bazié ${ }^{{ }^{* \dagger}}$, Diane Yirgnur Somé ${ }^{\dagger}$, Isidore Tiandiogo Traoré ${ }^{1,2}$, Anselme Sanon ${ }^{1}$, \\ Issouf Konaté ${ }^{1,2}$, Souleymane Tassembedo ${ }^{1}$, Ajani Ousmane Taofiki ${ }^{1}$, Dramane Kania', Abdoulaye Ouédraogo ${ }^{1}$, \\ Bea Vuylsteke ${ }^{3}$, Caroline Gilbert ${ }^{4}$, Nicolas Meda ${ }^{1,5}$, Abdoul Salam Ouédraogo $^{2}$ and Nicolas Nagot ${ }^{6}$
}

\begin{abstract}
Background: In people living with HIV/AIDS (PLWHA), initiation of antiretroviral therapy (ART) leads to sustained effective suppression of viral replication and increasing CD4 +T cell count. However, a fraction of ART-treated patients still fail to reach adequate CD4 + T cell number despite a suppressed viral load $(\mathrm{VL})$, and this phenomenon is defined as immunovirological discordance (IVD). In Africa, several studies have reported immunovirological outcomes of antiretroviral therapy, but little is known about IVD occurrence in Female sex workers (FSW). This study aimed to assess the prevalence of IVD and associated factors among a cohort of HIV infected FSW in Burkina Faso.
\end{abstract}

Methods: We conducted a cohort study from December 2003 to October 2016. Immunovirological discordance was defined as CD4 + T cell gain $<100$ cells/ $\mu \mathrm{L}$ despite a suppressed $V L(V L<1000$ copies $/ \mathrm{mL}) 12$ months after ART initiation. The CD4 + T cells were counted using BD FACSCount ${ }^{\mathrm{TM}}$ System and point of care Pima ${ }^{\mathrm{TM}}$ CD4 + Analyzer. HIV-1 RNA was quantified by real-time polymerase-chain-reaction assay with the use of the ABI 7000 system. We conducted a logistic regression to identify factors associated with discordant responses.

Results: Among the 123 HIV-1 infected FSW having at least 12 months follow-up on ART, 105 (85.4\%) achieved HIV-1 RNA suppression. Among the latter 25 gained less than 100 CD4+T cells within 12 months follow-up. The IVD rate was 23.8\% (95\% CI 16.04\%-33.11\%). After adjustment for age, WHO clinical stage and ART regimen including nucleoside/nucleotide reverse transcriptase inhibitors, only baseline CD4+T cell count between 200 to 350 cells/ $\mu \mathrm{L}$ (adjusted OR: 4.15; 95\%Cl 1.13-15.22) and 350 to 500 cells/ $\mu \mathrm{L}$ (adjusted OR: 17.50; 95\%Cl 2.68-114.31) remain significantly associated with IVD occurrence.

Conclusions: Immunovirological discordance response was common in FSW with proportions close to those observed in the general population. A diagnosis and personalized follow-up of patients who do not achieve full immune reconstitution would make it possible to avoid complications in terms of morbidity and mortality.

Keywords: HIV-1, Antiretroviral therapy, Immunovirological discordance, Female sex workers, Burkina Faso

*Correspondence: bww_wens@yahoo.fr

†Wilfried Wenceslas Bazié and Diane Yirgnur Somé contributed equally to this work

${ }^{1}$ Centre Muraz, Institut National de Santé Publique, 2054 Avenue Mamadou Konaté01 BP 390, Bobo-Dioulasso, Burkina Faso

Full list of author information is available at the end of the article

\section{Background}

In people living with HIV/AIDS (PLWHA), initiation of the antiretroviral therapy (ART) lead to sustained effective suppression of viral replication, increasing $\mathrm{CD} 4+\mathrm{T}$ cell count, reversal of most immunological disturbances, and reduction in risk of morbidity 
and mortality [1]. However, a fraction of ART-treated patients still fail to fully recover adequate $\mathrm{CD} 4+\mathrm{T}$ cell number despite a suppressed viral load (VL). This phenomenon is referred to by various terms including discordant immune responders or immunovirological discordance (IVD) and has been associated with increased morbidity and mortality [2, 3]. However, there is no consensus on the time, the gain or the $\mathrm{CD} 4+\mathrm{T}$ cell number to define this phenomenon. A systematic review reported that among patients with the discordant outcome, the risk of mortality ranged from 3 to $23 \%$ versus $1 \%$ to $7 \%$ for those with good immunological responses [4].

In resource constrained countries including Africa, Latin America, and Asia, the antiretroviral therapy collaboration network reported an IVD prevalence of $19.07 \%$ after six months on ART [5]. Recent studies conducted in the general population particularly in Africa reported an IVD prevalence of $14 \%$ in Burkina Faso in 2012 [6], 16\% in Nigeria in 2013 [7], 29\% in Rwanda in 2016 [8] and, 2.70\% in Tigray, Northern Ethiopia in 2021 [9]. In current practice, IVD remains underdiagnosed or neglected for many reasons. WHO recommends that in settings where routine viral load monitoring is available, $\mathrm{CD} 4+\mathrm{T}$ cell count monitoring can be stopped in individuals who are stable on ART and virally suppressed [10] and this limits the follow-up of immunological recovery. Moreover, logistical constraints with recurring stockouts of reagents and devices failure make IVD assessment difficult or often impossible to implement.

Multiple factors have been associated with IVD occurrence but none of these factors provides a full explanation for the lack of immune reconstitution [11-15]. Sociodemographic factors such as older age at ART initiation [7, 16, 17], male sex [7] have been associated with IVD. Furthermore, biological, and clinical factors such as coinfection and immune activation [18-20], CD4+ T cell count at ART initiation $[5,16,21,22]$, poor adherence [2, 23], treatment regimen (containing Zidovudine or Lamivudine/Zidovudine) $[2,24]$ have also been associated with IVD occurrence.

In Africa, several studies have reported immunovirological outcomes of ART but few of them have been focused on IVD assessment in Female Sex Workers (FSW). Whereas, FSW are exposed to multiple factors that could favor IVD occurrence namely, substance use, ART non-adherence, coinfections due to the high frequency of viral and bacterial sexually transmitted infections (STI) [12, 25, 26], likely increasing immune activation. The IVD rates among FSWs may highlight the need for targeted interventions to improve ART access and immunovirological monitoring to maximize the benefit of ART and limit the spread of HIV.
Knowing that the immune reconstitution that occurs during ART is essential for successful treatment of PLWHA and the lack of data on IVD occurrence among FSW, we sought to assess the prevalence of IVD and its associated factors at 12 months follow up in FSW living with HIV in Burkina Faso.

\section{Methods}

\section{Study design and setting}

We analyzed data from an open cohort of high-risk women followed up from December 2003 to October 2016 ('Yerelon' cohort, ANRS 1222), as described previously [27-29]. This cohort was implemented in a Clinic that provides HIV prevention and care services to professional or non-professional FSW, with strong involvement of community-based organizations (CBO) [27-29].

\section{Participants}

Cohort of HIV infected and uninfected FSW were recruited through a network of peer educators, then enrolled after informed consent. The recruitment and inclusion have been described elsewhere [27-29]. Briefly, women working in the streets and bars of Bobo-Dioulasso were eligible for the cohort if they reported at least two transactional sex acts per week, were aged 16 years or older and were willing to undergo regular testing for HIV and STI. Other women were recruited from HIV $\mathrm{CBO}$, using the same criteria. We included in this analysis all HIV infected women who fulfilled the following criteria: infected with HIV-1, aged at least 18 years, initiated antiretroviral treatment at the Yerelon clinic from December 2003 to October 2016, being on antiretroviral therapy for at least 12 months, having CD $4+\mathrm{T}$ cell count results at ART initiation $<500$ cells $/ \mu \mathrm{L}$, having $\mathrm{CD} 4+\mathrm{T}$ cell count and viral load results at 12 months after ART initiation. The threshold of 500 cells $/ \mu \mathrm{L}$ was chosen because it represents the lower limit of the normal value range of $\mathrm{CD} 4+\mathrm{T}$ cells in healthy conditions [30].

\section{Data sources}

Collected variables included socio-demographic characteristics, clinical and biological data at ART initiation, and 12 months follow-up on ART. Study participants who started ART were followed at closer intervals: weekly during the first two weeks, and monthly during the whole follow-up for clinical examination, detection of drug adverse effects, and counseling on adherence [28]. Adherence was measured by pill counts and pharmacy refills at each visit during follow up and adherence data were obtained by averaging ART adherence at each visit during the first 12 months. 


\section{Antiretroviral therapy}

ART was initiated and monitored according to national guidelines adapted from the WHO recommendation for each period [31]. The first line triple drug combination treatment included two nucleoside/nucleotide reverse transcriptase inhibitors (NRTIs) and either a non-nucleoside reverse transcriptase inhibitor (NNRTIs) or a protease inhibitor (IP) (for HIV-1 and HIV-2 coinfection). The available NRTIs molecules (Zidovudine, Lamivudine, Stavudine, Tenofovir Dixoproxil Fumarate, and Emtricitabine), NRTIs (Nevirapine and Efavirenz), and PI (Crixivan and Viracept) were used.

\section{Biological measurements}

Blood samples were collected in EDTA-containing tubes. The CD4 $+\mathrm{T}$ cells were counted using BD FACSCount ${ }^{\mathrm{TM}}$ System (Becton Dickinson, USA) and point of care Pima $^{\mathrm{TM}}$ CD4 + Analyzer (Alere, Germany).

BD FACSCount ${ }^{\mathrm{TM}}$ CD4 reagents are complete kits used to enumerate the absolute counts and the percentage of CD4 + T lymphocytes. Briefly, $50 \mu \mathrm{L}$ of adequately mixed EDTA whole blood was added into the reagent tube. The tube was vortexed for $6 \mathrm{~s}$ and incubated for $30 \mathrm{~min}$ at room temperature in the workstation protected from light. Then, $50 \mu \mathrm{L}$ of the fixative solution was added and vortexed upright for $6 \mathrm{~s}$ before being analyzed with the BD FACSCount instrument.

The Pima CD4 test comprises a disposable Pima CD4 test cartridge and the Pima Analyser. It is an automated, image-based immune hematology test intended for the absolute $\mathrm{CD} 3+/ \mathrm{CD} 4+\mathrm{T}$ lymphocyte counts in whole blood. Succinctly, $25 \mu \mathrm{L}$ of adequately mixed EDTA whole blood was added into the sample collector of the Pima CD4 test cartridge. Then, Insert the Pima CD4 test cartridge into the Pima Analyser to run a test.

For viral load measurement, briefly, RNA was extracted manually from plasma using the QIAamp viral RNA mini kit (QIAGEN, Courtaboeuf, France). HIV-1 RNA was quantified by real-time polymerase-chain-reaction assay with the use of the ABI 7000 system (Applied Biosystems) as described previously [32]. The lower limit of detection was 300 copies/ml $(2.48 \log 10)$. During this period, the Centre Muraz laboratory participated in an external quality-control program for HIV-1 RNA quantitation organized by ANRS.

\section{Definitions}

There is no consensus in the literature on how best to define immunologic response or immunological failure during ART and it is not clear which criteria are optimal. Aldrete et al. [33] exploring the longitudinal relationship between CD4+ T cell count and composite clinical event shown that $C D 4+$ slope $\geq 100$ cells $/ \mu \mathrm{L} /$ year after $\mathrm{ART}$ initiation was associated with lower rates of AIDS, serious non-AIDS events, and death. In this analysis, in harmony with Aldrete, IVD was defined by the increase of less than $100 \mathrm{CD} 4+\mathrm{T}$ cells $/ \mu \mathrm{L}$ at 12 months compared to baseline despite virological suppression $(\mathrm{VL}<1000$ copies/ml).

Good adherence to ART was defined as adherence rate $>95 \%$ and poor adherence as $<95 \%$ [34].

\section{Statistical analysis}

Statistical analyses were performed with Epi Info $^{\text {TM }} 7$. Categorical variables were expressed as frequency and/or percentage (\%) whereas quantitative variables as median with interquartile range (IQR). Logistic regression by stepwise model selection was used to analyze predictors of IVD in univariate and multivariate analyses. The independent variables were included in the multivariate model if they had a $\mathrm{p}$-value $\leq 0.20$ on bivariate analysis. The variable age and WHO clinical stage were forced in the final model irrespective of $\mathrm{p}$ values. $\mathrm{P}$ values $<0.05$ were considered statistically significant.

\section{Results}

Baseline characteristics of patients

Of 243 cohort participants who started ART during the study period, 123 met inclusion criteria for this analysis (Fig. 1).

The median age of these 123 patients at ART initiation was 33 years (IQR 29-39) and 76.4\% were single or widowed or divorced. At ART initiation, $52.0 \%$ were at WHO clinical stages 3 or 4 , and the median CD4 $+\mathrm{T}$ cell count was 147 (IQR 79-200) cells/ $\mu \mathrm{L}$. Regarding ART molecules, most patients $83(67.5 \%)$ started the Efavirenzbased regimen, and 73 (59.3\%) a Zidovudine-based regimen (Table 1). Additional baseline characteristics are shown in Table 1.

\section{FSW virologic response to treatment and CD4 $+T$ cells recovery}

At 12 months follow-up of 123 ART-treated participants, 105 (85.4\%) had attained VL suppression (VL $<1000$ copies $/ \mathrm{mL}$ ) (Table 2). Compared to those with unsuppressed VL, no significant difference was observed with patients who have suppressed VL at 12 months respectively in terms of baseline median age (30.8 (IQR 27.69-40.15) vs 33.02 (IQR 30.01-39.02) p=0.5694), baseline median CD4+ T cell count (158 (IQR 130-214) vs 139 (IQR 74-200) $\mathrm{p}=0.2144$ ), and baseline median VL (4.80 (IQR $4.02-4.85$ ) vs 5.26 (IQR 4.85-5.58) $\mathrm{p}=0.0687$ ) (Table 2).

Concerning immunologic response based on $\mathrm{CD} 4+\mathrm{T}$ cell count recovery, four patients lost CD4 $+\mathrm{T}$ cells, and the median increase of CD $4+\mathrm{T}$ cells among 


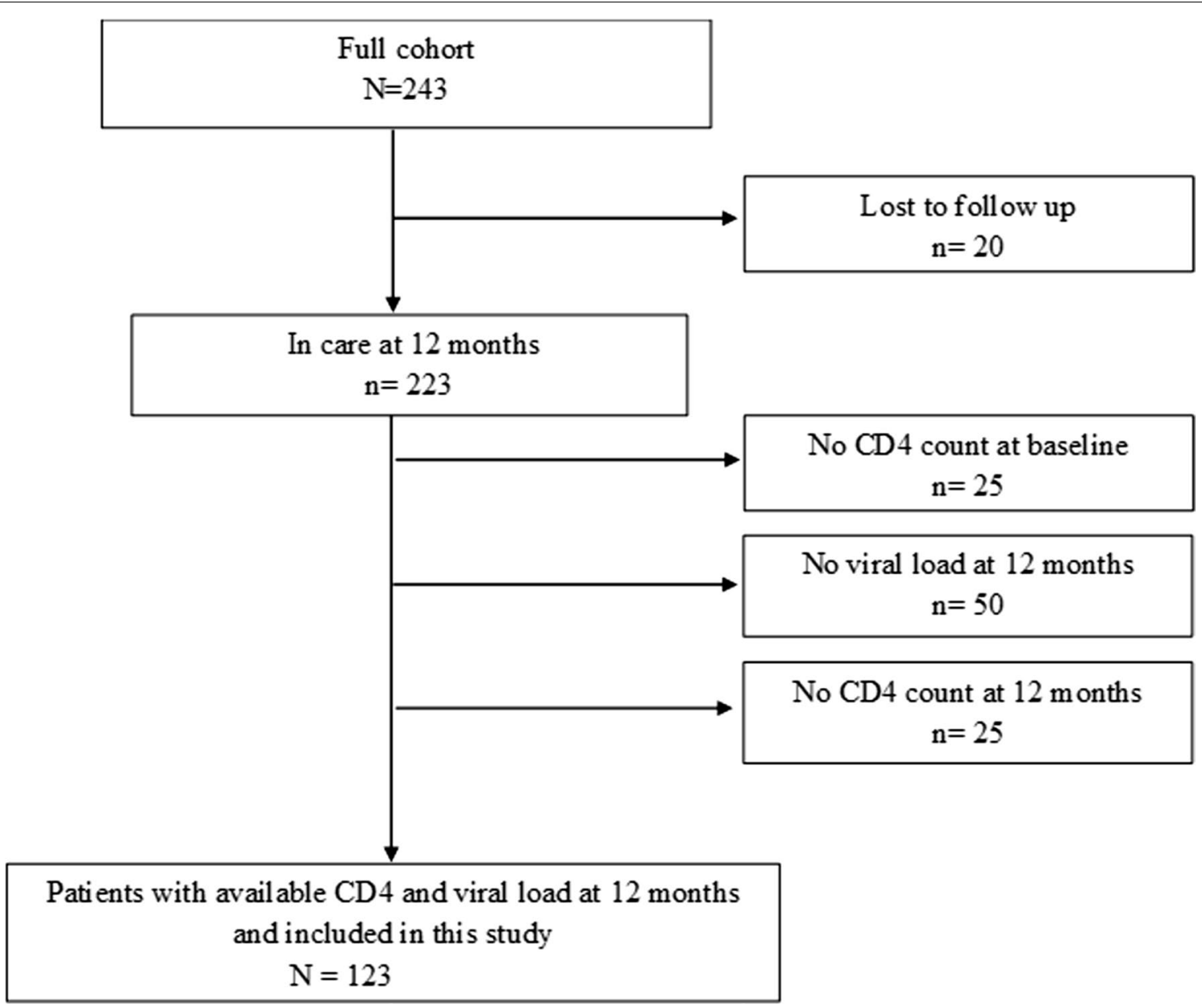

Fig. 1 Flowchart of the Yerelon cohort patient who initiated antiretroviral therapy during study period and evaluated as part of this study

119 patients who gained was 167 cells $/ \mu \mathrm{L}$ (IQR 89-286). Irrespective of VL suppression, 86 patients $(69.9 \%)$ achieved a $\mathrm{CD} 4+\mathrm{T}$ cells gain greater than 100 cells after 12 months of treatment (Table 2) with a median gain of $218 \mathrm{CD} 4+\mathrm{T}$ cells (IQR 160-311). These patients seem to have significantly fewer baseline CD4 + T cells compared to others (136 (IQR 75-192) vs 181 (IQR 109-343), $\mathrm{p}=0.0046$ ).

When we assessed immunologic recovery as a function of VL suppression status $(\mathrm{VL}<1000$ copies/mL), the IVD rate was $23.8 \%$ (95\%CI $16.04 \%-33.11 \%$ ).

At 12 months follow-up, 78 (63.4\%) patients achieved good adherence with a median ART adherence rate of 98.6\% (IQR 97.0-100). The adherence rate was 97.0\% (IQR 93.5-99.6) for those with suppressed VL and 96.4\% (IQR 95.3-100) for those who presented an IVD. Table 1 presents the baseline characteristics of patients who obtained a plasma HIV RNA level $<1000$ copies/ $\mathrm{mL}$ at 12 months and who presented an IVD.

\section{Factors associated with immunovirological discordance}

We next evaluated factors associated with IVD in 105 patients who obtained VL suppression. In bivariate analysis, patients with baseline $\mathrm{CD} 4+\mathrm{T}$ cell count between 200 and 350 cells (OR: 3.50; 95\%CI 1.13-10.83) and between 350 and 500 cells (OR: 21.00; 95\%CI 3.85114.51) were more likely to present IVD at 12 months on ART compared to those with CD4+ T cell count below 200 cells $/ \mu \mathrm{L}$ (Table 3). Besides, participants who had ART regimens that included stavudine (OR: 0.12; 95\%CI 0.02-0.74) were less at risk to present IVD compared to those initiated with ART regiments that included tenofovir (Table 3).

On the other hand, patients who initiated antiretroviral regimens that included efavirenz as NNRTI tended to be more likely to have IVD after 12 months (OR: 1.89; 95\%CI 0.63-5.61). Other factors like age, body mass index, and WHO clinical stage were not associated with IVD occurrence at 12 months on ART (Table 3). 
Table 1 Yerelon cohort patient who initiated antiretroviral study participants baseline characteristics

\begin{tabular}{|c|c|c|c|c|}
\hline Variable at ART initiation & $\begin{array}{l}\text { All Patients }(n=123) \\
n(\%)\end{array}$ & $\begin{array}{l}\text { Patients with HIV-1 RNA } \\
\text { suppressed at } 12 \text { months on } \\
\text { ART } \\
(\mathrm{VL}<1000 \text { copies } / \mathrm{mL}) \\
(\mathrm{n}=105) \\
\mathrm{n}(\%)\end{array}$ & $\begin{array}{l}\text { Immunologic responder } \\
\text { at } 12 \text { months on ART } \\
\text { (CD4+T cell } \\
\text { recovery } \geq 100 \text { cells) } \\
(n=86) \\
n(\%)\end{array}$ & $\begin{array}{l}\text { Patients with } \\
\text { immunovirological } \\
\text { discordance at } 12 \text { months } \\
(\mathrm{n}=25) \\
\mathrm{n}(\%)\end{array}$ \\
\hline Age: median (IQR) years & $33.00(29.00-39.17)$ & $33.02(30.01-39.02)$ & $32.93(28.5-38.80)$ & $33.00(31.00-39.23)$ \\
\hline$<30$ & $31(25.20)$ & $25(23.81)$ & $23(26.74)$ & $4(16.00)$ \\
\hline $30-39$ & $65(52.85)$ & $58(55.24)$ & $46(53.49)$ & $15(60.00)$ \\
\hline$\geq 40$ & $27(21.95)$ & $22(20.95)$ & $17(19.77)$ & $6(24.00)$ \\
\hline \multicolumn{5}{|l|}{ Education level } \\
\hline None & $52(42.28)$ & $45(42.86)$ & $38(44.19)$ & $9(36.00)$ \\
\hline Primary school & $36(29.27)$ & $31(29.52)$ & $23(26.74)$ & $11(44)$. \\
\hline Secondary school & $35(28.45$ & $29(27.62)$ & $25(29.07)$ & $5(20.00)$ \\
\hline \multicolumn{5}{|l|}{ Marital status (couple life) } \\
\hline Yes & $29(23.58)$ & $23(21.90)$ & $21(24.42)$ & $4(16.00)$ \\
\hline No & $94(76.42)$ & $82(78.10)$ & $65(75.58)$ & $21(8400)$ \\
\hline \multicolumn{5}{|l|}{ WHO clinical stage } \\
\hline 1 & $17(13.82)$ & $13(12.38)$ & $12(13.95)$ & $3(12.00)$ \\
\hline 2 & $42(34.15)$ & $35(33.33)$ & $29(33.72)$ & $8(32.00)$ \\
\hline 3 and 4 & $64(52.03)$ & $57(54.29)$ & $45(52.33)$ & $14(56.00)$ \\
\hline Body mass index: median (IQR) & $20.60(18.55-22.72)$ & $20.58(18.13-22.55)$ & $20.38(18.24-22.37)$ & $20.76(18.55-23.51)$ \\
\hline$<18,5$ & $29(23.58)$ & $28(26.67)$ & $23(26.74)$ & $6(24.00)$ \\
\hline $18,5-25$ & $83(67.48)$ & $67(63.81)$ & $57(66.28)$ & $15(60.00)$ \\
\hline$>25$ & $11(8.94)$ & $10(9.52)$ & $6(6.98)$ & $4(16.00)$ \\
\hline $\begin{array}{l}\text { CD4+T cell count at ART } \\
\text { initiation: } \\
\text { Median (IQR) }\end{array}$ & $147(79-200)$ & $139(74-200)$ & $136(75-192)$ & $238(100-384)$ \\
\hline$<200$ & $90(73.17)$ & $77(73.33)$ & $70(81.40)$ & $11(44.00)$ \\
\hline $200-349$ & $23(18.70)$ & $19(18.10)$ & $14(16.28)$ & $7(28.00)$ \\
\hline $350-500$ & $10(8.13)$ & $9(8.57)$ & $2(2.33)$ & $7(28.00)$ \\
\hline $\begin{array}{l}\text { HIV-1 Viral load (log 10copies/ } \\
\text { ml): median (IQR) }(n=52)\end{array}$ & $5.20(4.82-5.52)$ & $5.26(4.85-5.58)$ & $5.18(4.82-5.54)$ & $5.43(5.28-5.65)$ \\
\hline$<3 \log 10$ & $2(3.85)$ & $2(4.17)$ & $2(4.76)$ & - \\
\hline $3-5 \log 10$ & $16(30.77)$ & $13(27.08)$ & $13(30.95)$ & $1(12.50)$ \\
\hline$>5 \log 10$ & $34(65.38)$ & $33(68.75)$ & $27(64.29)$ & $7(87.50)$ \\
\hline \multicolumn{5}{|l|}{ ART NNRTIs initiated } \\
\hline Nevirapine & $38(30.89)$ & $30(28.57)$ & $28(32.56)$ & $5(20.00)$ \\
\hline Efavirenz & $83(67.48)$ & $73(69.52)$ & $56(65.12)$ & $20(80.00)$ \\
\hline Protease inibitor & $2(1.63)$ & $2(1.90)$ & $2(2.33)$ & \\
\hline \multicolumn{5}{|l|}{ ART NRTIs initiated } \\
\hline Tenofovir & $18(14.63)$ & $15(14.29)$ & $11(12.79)$ & $6(24.00)$ \\
\hline Zidovudine & $73(59.35)$ & $64(60.95)$ & $49(56.98)$ & $17(68.00)$ \\
\hline Stavudine & $32(26.02)$ & $26(24.76)$ & $26(30.23)$ & $2(8.00)$ \\
\hline ART Adherence: median (IQR) & $97.00(92.5-99.40$ & $97.00(93.5-99.65)$ & $97.00(92.00-99.40)$ & $96.40(95.30-100)$ \\
\hline$<95 \%$ & 45 (36.59) & $37(35.24)$ & $35(40.70)$ & $6(24)$ \\
\hline$\geq 95 \%$ & $78(63.41)$ & $68(64.76)$ & $51(59.30)$ & $19(76)$ \\
\hline
\end{tabular}

$\overline{A R T}$ antiretroviral therapy, IQR interquartile range, NNRT/s non-nucleoside reverse transcriptase inhibitors, NRT/s nucleoside/nucleotide reverse transcriptase inhibitors

At multivariate analysis, after adjustment for age, WHO clinical stage, and ART regimen including NRTIs, only baseline CD $4+\mathrm{T}$ cell count between 200 and 350 cells $/ \mu \mathrm{l}$ (adjusted Odds Ratio (aOR): 4.15; 95\%CI 1.13-15.22) and between 350 and 500 cells/ $\mu$ laOR: 17.50; 95\%CI 2.68114.31) remain significantly associated with IVD occurrence (Table 3). 
Table 2 Virological and immunological treatment responses at 12 months among Yerelon cohort patients who initiated antiretroviral

\begin{tabular}{|c|c|c|c|c|}
\hline & \multicolumn{2}{|l|}{ Viral Load } & \multirow[t]{2}{*}{ Total } & \multirow[t]{2}{*}{ P-value } \\
\hline & $<1000$ copies /mL n (\%) & $\geq 1000$ copies $/ \mathrm{mL} n(\%)$ & & \\
\hline \multicolumn{5}{|l|}{ CD4 $+\mathrm{T}$ cell increase } \\
\hline$<100$ cells & $25(23.81)$ & $12(66.67)$ & 37 & \\
\hline$\geq 100$ cells & $80(76.19)$ & $6(33.33)$ & 86 & 0.0003 \\
\hline Total & 105 & 18 & 123 & \\
\hline Baseline age: median (IQR) & $33.02(30.01-39.02)$ & $30.8(27.69-40.15)$ & & 0.5694 \\
\hline Baseline CD4 + T cell count: median (IQR) & $139(74-200)$ & $158(130-214$ & & 0.2144 \\
\hline HIV-1 Viral load (log 10copies/mL): median (IQR) & $5.26(4.85-5.58$ & $4.80(4.02-4.85$ & & 0.0687 \\
\hline
\end{tabular}

Table 3 Factors associated with immunovirological discordance at 12 months on antiretroviral therapy at univariate and multivariate logistic regression

\begin{tabular}{|c|c|c|c|c|c|}
\hline Variable & $\begin{array}{l}\mathrm{n}(\%) \text { of } \\
\text { immunovirological } \\
\text { discordance }\end{array}$ & $\begin{array}{l}\text { Odds Ratio } \\
(95 \% \mathrm{Cl})\end{array}$ & $P$ & $\begin{array}{l}\text { Adjusted Odds Ratio } \\
(95 \% \mathrm{Cl})\end{array}$ & $P$ \\
\hline Age (years) & & & 0.3540 & & 0.5032 \\
\hline$<30$ & $4(16.00)$ & 1 & & 1 & \\
\hline $30-39$ & $15(60.00)$ & $1.83(0,54-6.20)$ & & $1.55(0.39-6.10)$ & 0.5323 \\
\hline$\geq 40$ & $6(24.00)$ & $1.97(0.47-8.16)$ & & $1.76(0.33-9.28)$ & 0.5050 \\
\hline Marital status (couple life) & & & 0.4166 & & \\
\hline No & $4(16.00)$ & 1 & & & \\
\hline Yes & $21(8400)$ & $0.61(0.19-2.00)$ & & & \\
\hline BMI Class & & & 0.3658 & & \\
\hline$<18,5$ & $6(24.00)$ & 1 & & & \\
\hline $18,5-25$ & $15(60.00)$ & $1.06(0.36-3.08)$ & & & \\
\hline$>25$ & $4(16.00)$ & $2.44(0.52-11.56)$ & & & \\
\hline WHO clinical stage & & & 0.8640 & & 0.5306 \\
\hline 1 & $3(12.00)$ & 1 & & 1 & \\
\hline 2 & $8(32.00)$ & $0.99(0.22-4.48)$ & & $0.82(0.13-4.98)$ & 0.8300 \\
\hline 3 and 4 & $14(56.00)$ & $1.08(0.26-4.51)$ & & $1.28(0.24-6.65)$ & 0.7716 \\
\hline CD4+T cell count (cells/ $\mu l)$ & & & 0.0001 & & 0.0012 \\
\hline$<200$ & $11(44.00)$ & 1 & & 1 & \\
\hline $200-349$ & $7(28.00)$ & $3.50(1.13-10.83)$ & & $4.15(1.13-15.22)$ & 0.0317 \\
\hline $350-500$ & $7(28.00)$ & $21.00(3.85-114.51)$ & & $17.50(2.68-114.31)$ & 0.0028 \\
\hline ART NNRTIs initiated & & & 0.4313 & & \\
\hline Nevirapine & $5(20.00)$ & 1 & & & \\
\hline Efavirenz & $20(80.00)$ & $1.89(0.63-5.61)$ & & & \\
\hline Protease inhibitor & & - & & & \\
\hline ART NRTIs initiated & & & 0.0170 & & 0.1800 \\
\hline Tenofovir & $6(24.00)$ & 1 & & 1 & \\
\hline Zidovudine & $17(68.00)$ & $0.54(0.16-1.75)$ & & $1.19(0.27-5.29)$ & 0.8177 \\
\hline Stavudine & $2(8.00)$ & $0.12(0.02-0.74)$ & & $0.28(0.04-2.11)$ & 0.2183 \\
\hline ART Adherence & & & 0.2495 & & \\
\hline$<95 \%$ & $6(24)$ & 1 & & & \\
\hline$\geq 95 \%$ & $19(76)$ & $2.00(0.72-5.56)$ & & & \\
\hline
\end{tabular}




\section{Discussion}

The frequency of IVD in our population of FSW was 23.81\% after 12 months of follow-up on ART. This finding was similar to previous reports in the general population which noticed that $10-30 \%$ of all HIV-infected patients do not achieve optimal immune reconstitution despite suppression of viral replication [2, 5, 8, 15, 16, 35]. It is important to note that there is no consensus in the literature on how best to define IVD. Some studies define IVD as a failure to achieve a pre-specified absolute CD $4+\mathrm{T}$ cell count (threshold) at a particular time point. Most of these studies focus on a threshold (i.e. $<200$ or $<350$ cells/ $\mu \mathrm{L}$ ) derived from prior guidelines that determined the timing of ART initiation and risk of opportunistic infections $[9,14,30]$. Others require a pre-specified increase in $\mathrm{CD} 4+\mathrm{T}$ cell count irrespective of the initial value in percentage or a threshold value to define IVD $[8,14$, 33]. Likewise, the suppressed or undetectable viral load threshold changes according to the studies. This multitude of definitions makes it difficult to compare the different studies in addition to the fact that they are carried out in different contexts and populations. There is a need for agreement on defining IVD for standardization across the different ways of identifying it.

In this study, a discordant response was associated with a higher $\mathrm{CD} 4+\mathrm{T}$ cell count above 200 cells/ $\mu \mathrm{l}$ at ART initiation. Other studies have reported similar findings to ours, with higher pre-therapy $\mathrm{CD} 4+\mathrm{T}$ cell count being associated with smaller gains in $\mathrm{CD} 4+\mathrm{T}$ cell count at 12 months [5, 16, 23]. Tuboi [5] and Moore [2] reported that increases in CD4 $+\mathrm{T}$ cell count after initiation of therapy might be greater in individuals with lower $\mathrm{CD} 4+\mathrm{T}$ cell count at therapy initiation.

Contrariwise, some studies reported that a low baseline CD4 $+\mathrm{T}$ cell count was predictive of immunological discordant treatment responses [9, 36, 37] while some others found no association between baseline CD4+ T cell count and IVD [8]. After ART initiation, the initial increase in CD4 + T cell count is usually observed in the first 3-6 months [38]. Several factors including impaired bone marrow hematopoietic function and decreased proliferative capacity, lower thymic output, dysfunction in some cytokines expressions, and $\mathrm{CD} 4+\mathrm{T}$ cells destructions may have an important role in the achievement of optimal immune reconstitution [13-15].

Another contributing factor that could particularly expose FSW to IVD and not assessed in our study is coinfection with other pathogens which is prevalent in Africa $[39,40]$. Numerous studies have found that hepatitis $\mathrm{B}$ virus, hepatitis $\mathrm{C}$ virus, and cytomegalovirus coinfections were associated with poor $\mathrm{CD} 4+\mathrm{T}$ cells immune recovery in HIV-1-infected individuals on ART $[13,41,42]$. The mechanism by which coinfections may have deleterious effects on $\mathrm{CD} 4+\mathrm{T}$ cell count recovery is linked to its contribution to immune activation. Hunt et al. [19] found that with every $5 \%$ increase in the percentage of activated CD8 $\mathrm{T}$ cells, the CD4 $+\mathrm{T}$ cell count decreased by 35 cells $/ \mu \mathrm{L}$ after 3 months of ART. Over study indicated that $\mathrm{T}$ cell activation driven by monocyte activation demonstrated by Soluble CD14 and soluble CD163 levels is associated with poor immune recovery in HIV-1 infected individuals [43].

In contrast to most of the studies, age was not associated with IVD in our study. In the evaluation of immune recovery, younger age was described to predict greater early CD4 $+\mathrm{T}$ cell gain and supporting the importance of thymic function $[13,17,44,45]$. Our participants were relatively younger with a median age of 33 years. In fact, older patients were more likely to experience poorer immunologic responses that could be potentiated by HIV induced immunosenescence [13, 23]. Moreover, the normal aging process leads to the gradual change of thymic tissue into fatty tissue and this may also explain why older people are at higher risk of incomplete immune restoration [14].

Unexpectedly, patients that initiated therapy with a tenofovir containing regimen were more likely to develop IVD than patients on a Zidovudine or stavudine containing regimen. This could probably be explained by the fact that tenofovir was introduced when the threshold for CD4 count to initiate ARV treatment was 350 cells. In addition, the relatively small number of patients on tenofovir compared to other molecules could also explain these results. However, evidence on nucleoside/nucleotide reverse transcriptase inhibitors effect on $\mathrm{CD} 4+\mathrm{T}$ cells recovery was controversial $[35,46,47]$. Most of our patients were on a regimen including a NNRTI rather than a protease inhibitor. However, compared to NNRT, protease inhibitors based regimens were shown to modulate the activation of peripheral blood CD $4+\mathrm{T}$ cells, decrease their susceptibility to apoptosis therefore promote their increase [48].

Contrary to Abrogoua et al. [49] who noticed that adherence to ART is an important predictor of immunological response, no significant association between IVD and ART adherence was observed. We think that in the lack of an objective method for adherence assessment (drug assay in the blood), it is difficult to attribute IVD to an adherence problem.

To date, no antiretroviral or immune system-based strategy has yet demonstrated a clinically meaningful outcome in the treatment of IVD. Some data support less frequent $\mathrm{CD} 4+\mathrm{T}$ cell monitoring in clinically stable virally suppressed patients and suggest that routine $\mathrm{CD} 4+\mathrm{T}$ cell monitoring for this population may be unnecessary $[50,51]$. For us, rather than suppressing the 
$\mathrm{CD} 4+\mathrm{T}$ count in all patients with suppressed viral load, we believe that for personalized medicine it would be desirable to maintain annual monitoring of the CD4 $+\mathrm{T}$ cell count in patients with IVD. Its measure would not only permit to discontinue but also to restart the prophylaxis for opportunistic infections.

Our study has some limitations. Some findings could be explained by the relatively small size of the sample, which does not ensure sufficient power to be able to extrapolate the statistical analysis results to the overall population. We did not have baseline HIV-1 RNA measurements for more than half of the patients. These results would have made it possible to better assess the evolution of viral load under ART. The CD4+ T cell count was not performed with the same counting device for all patients. A study showed a $2 \%$ difference between the results of the CD4+ T cell count performed with the BD FACSCount device and the Pima analyzer from a threshold of 350 cells/ $\mu \mathrm{L}$ [52]. As a result, patients may be wrongly considered to be in discordance.

\section{Conclusion}

Despite the difficult context linked to the lack of a consensual definition of IVD and the period over which it must be evaluated, our results show a frequency of IVD in FSW comparable to those observed in the general population. Despite several pejorative considerations, the monitoring set up in the Yerelon cohort makes it possible to obtain the same rates of IVD in FSW as in the general population. A better understanding of IVD occurrence and associated factors may lead to better therapies to improve the level of immune reconstitution and ultimately the possible development of adjuvants that reverse the immunologic perturbations caused by HIV infection and that persist despite ART induced viral suppression.

\section{Abbreviations}

ART: Antiretroviral therapy; VL: Viral load; IVD: Immunovirological discordance; FSW: Female sex workers; STI: Sexually transmitted infections; CBO: Community-based organizations; NRTIs: Nucleoside/nucleotide reverse transcriptase inhibitors; NNRTIs: Non-nucleoside reverse transcriptase inhibitors; IP: Protease inhibitor; IQR: Interquartile range; OR: Odds ratio; aOR: Adjusted OR.

\footnotetext{
Acknowledgements

We thank the women and the organizations of people living with HIV/ AIDS who participated in this study. We acknowledge the Ministry of Health and the National Program for AIDS control and the "service d'hygiène" of Bobo-Dioulasso. We are grateful to the Directorate-General for Development Cooperation and Humanitarian Aid of Belgium who supported Yerelon clinic activities through " Health research capacity building project in the context of Burkina Faso's limited resources".
}

\section{Authors' contributions}

WWB and DYS conceived study; DYS and WWB collected data; WWB and DYS analyzed data and drafted the manuscript; TIT, AS, IK, ST, AOT, DK, ASO, AO, BV,
CG, NM and NN critically revised the manuscript drafts. All authors read and approved the final manuscript.

Funding

The French Agence Nationale de Recherches sur le SIDA et les hépatites (ANRS) funded the Yerelon cohort study.

\section{Availability of data and materials}

The datasets used and/or analysed during the current study are available from the corresponding author on reasonable request.

\section{Declarations}

\section{Ethics approval and consent to participate}

The Yerelon cohort studies were approved by the Centre Muraz institutional review board (N/Ref./ 11-02/CE-CM, October 9, 2002), and the Burkina Faso National Ethics Committee (currently the Health Research Ethics Committee) ( N²003-005. April 22, 2003). This study was performed in accordance with the Declaration of Helsinki and all methods were performed in accordance with the relevant guidelines and regulations. All participants signed written informed consent before being included.

\section{Consent for publication}

Not applicable.

\section{Competing interests}

The authors declare that they have no competing interests.

\section{Author details}

${ }^{1}$ Centre Muraz, Institut National de Santé Publique, 2054 Avenue Mamadou Konaté01 BP 390, Bobo-Dioulasso, Burkina Faso. ${ }^{2}$ Institut Supérieur des Sciences de la Santé, Université Nazi Boni, Bobo-Dioulasso, Burkina Faso. ${ }^{3}$ Department of Public Health, Institute of Tropical Medicine, Antwerp, Belgium. ${ }^{4}$ Axe de Recherche Maladies Infectieuses et Immunitaires, Centre de Recherche du CHU de Québec-Université Laval, Québec, QC, Canada. ${ }^{5}$ Département de Santé Publique, Unité de Formation et de Recherche en Sciences de la Santé, Université Joseph Ki-Zerbo, Ouagadougou, Burkina Faso. ${ }^{6}$ INSERM, Université des Antilles, Etablissement Français du Sang, Montpellier, France.

Received: 19 September 2021 Accepted: 31 January 2022

Published online: 03 February 2022

\section{References}

1. Arici C, Ripamonti D, Ravasio V, Maggiolo F, Rizzi M, Finazzi MG, et al. Long-term clinical benefit after highly active antiretroviral therapy in advanced HIV-1 infection, even in patients without immune reconstitution. Int J STD AIDS. 2001;12(9):573-81.

2. Moore DM, Hogg RS, Yip B, Wood E, Tyndall M, Braitstein P, et al. Discordant immunologic and virologic responses to highly active antiretroviral therapy are associated with increased mortality and poor adherence to therapy. J Acquir Immune Defic Syndr. 2005;40(3):288-93.

3. Piketty C, Weiss L, Thomas F, Mohamed AS, Belec L, Kazatchkine MD. Long-term clinical outcome of human immunodeficiency virus-infected patients with discordant immunologic and virologic responses to a protease inhibitor-containing regimen. J Infect Dis. 2001;183(9):1328-35.

4. Kelly C, Gaskell KM, Richardson M, Klein N, Garner P, MacPherson P. Discordant immune response with antiretroviral therapy in HIV-1: a systematic review of clinical outcomes. PLOS ONE. 2016;11(6):e0156099.

5. Tuboi SH, Brinkhof MW, Egger M, Stone RA, Braitstein P, Nash D, et al. Discordant responses to potent antiretroviral treatment in previously naive HIV-1-infected adults initiating treatment in resource-constrained countries: the antiretroviral therapy in low-income countries (ART-LINC) collaboration. J Acquir Immune Defic Syndr. 2007;45(1):52-9.

6. Tiba F, Nauwelaers F, Traoré S, Coulibaly B, Ouedraogo T, Compaoré $A$, et al. Immune Reconstitution During the First Year of Antiretroviral Therapy of HIV-1-Infected Adults in Rural Burkina Faso. Open AIDS J. 2012;6:16-25. 
7. Anude CJ, Eze E, Onyegbutulem HC, Charurat M, Etiebet MA, Ajayi S, et al. Immuno-virologic outcomes and immuno-virologic discordance among adults alive and on anti-retroviral therapy at 12 months in Nigeria. BMC Infect Dis. 2013;13:113.

8. Kayigamba FR, Franke MF, Bakker MI, Rodriguez CA, Bagiruwigize E, Wit FW, et al. Discordant treatment responses to combination antiretroviral therapy in Rwanda: a prospective cohort study. PLoS ONE. 2016;11(7):e0159446.

9. Hailu GG, Wasihun AG. Immunological and virological discordance among people living with HIV on highly active antiretroviral therapy in Tigray, Northern Ethiopia. BMC Infect Dis. 2021;21(1):561.

10. WHO. What's new in treatment monitoring: viral load and CD4 testing Update. https://www.who.int/publications/i/item/WHO-HIV-2017.22-eng. pdf. Accessed 22 June 2021

11. Battegay M, Nüesch R, Hirschel B, Kaufmann GR. Immunological recovery and antiretroviral therapy in HIV-1 infection. Lancet Infect Dis. 2006;6(5):280-7.

12. Dambach P, Mahenge B, Mashasi I, Muya A, Barnhart DA, Bärnighausen TW, et al. Socio-demographic characteristics and risk factors for HIV transmission in female bar workers in sub-Saharan Africa: a systematic literature review. BMC Public Health. 2020;20(1):697.

13. Massanella M, Negredo E, Clotet B, Blanco J. Immunodiscordant responses to HAART-mechanisms and consequences. Expert Rev Clin Immunol. 2013;9(11):1135-49.

14. Gaardbo JC, Hartling HJ, Gerstoft J, Nielsen SD. Incomplete immune recovery in HIV infection: mechanisms, relevance for clinical care, and possible solutions. Clin Dev Immunol. 2012;2012:670957.

15. Yang $X$, Su B, Zhang $X$, Liu Y, Wu H, Zhang T. Incomplete immune reconstitution in HIV/AIDS patients on antiretroviral therapy: Challenges of immunological non-responders. J Leukoc Biol. 2020;107(4):597-612.

16. Gilson RJ, Man SL, Copas A, Rider A, Forsyth S, Hill T, et al. Discordant responses on starting highly active antiretroviral therapy: suboptimal CD4 increases despite early viral suppression in the UK Collaborative HIV Cohort (UK CHIC) Study. HIV Med. 2010;11(2):152-60.

17. Kaufmann GR, Bloch M, Finlayson R, Zaunders J, Smith D, Cooper DA. The extent of HIV-1-related immunodeficiency and age predict the longterm CD4 T lymphocyte response to potent antiretroviral therapy. AIDS. 2002;16(3):359-67.

18. Aiuti F, Mezzaroma I. Failure to reconstitute CD4+T-cells despite suppression of HIV replication under HAART. AIDS Rev. 2006;8(2):88-97.

19. Hunt PW, Martin JN, Sinclair E, Bredt B, Hagos E, Lampiris $H$, et al. T cell activation is associated with lower CD4+ T cell gains in human immunodeficiency virus-infected patients with sustained viral suppression during antiretroviral therapy. J Infect Dis. 2003;187(10):1534-43.

20. Mullins TLK, Li SX, Bethel J, Goodenow MM, Hudey S, Sleasman JW. Sexually transmitted infections and immune activation among HIVinfected but virally suppressed youth on antiretroviral therapy. J Clin Virol. 2018;102:7-11.

21. Falster K, Petoumenos K, Chuah J, Mijch A, Mulhall B, Kelly M, et al. Poor baseline immune function predicts an incomplete immune response to combination antiretroviral treatment despite sustained viral suppression. J Acquir Immune Defic Syndr. 2009;50(3):307-13.

22. Ouedraogo SM, Zoungrana J, Sondo KA, Kyelem CG, Koussé S, Hema A, et al. Immuno-virologic dissociation in patients infected by HIV-1 under antiretroviral treatment at the Day hospital of Bobo-Dioulasso from 2008 to 2012 (Burkina Faso). Mali Med. 2015;30(4):58-64.

23. Kà D, Manga NM, Ngom-Guéye NF, Ndiaga D, Diop M, Cisse-Diallo VMP, et al. Factors associated with immunovirologic dissociation in HIV-1-infected patients under highly active antiretroviral therapy in the Ambulatory Treatment Center (ATC) in Dakar. Pan Afr Med J. 2017;27:16.

24. Wandeler G, Gsponer T, Mulenga L, Garone D, Wood R, Maskew M, et al. Zidovudine impairs immunological recovery on first-line antiretroviral therapy: collaborative analysis of cohort studies in southern Africa. AIDS 2013;27(14):2225-32.

25. Lancaster KE, Cernigliaro D, Zulliger R, Fleming PF. HIV care and treatment experiences among female sex workers living with HIV in sub-Saharan Africa: A systematic review. Afr J AIDS Res. 2016;15(4):377-86.

26. Vandepitte J, Bukenya J, Weiss HA, Nakubulwa S, Francis SC, Hughes P, et al. HIV and other sexually transmitted infections in a cohort of women involved in high-risk sexual behavior in Kampala. Uganda Sex Transm Dis. 2011;38(4):316-23.
27. Nagot N, Ouedraogo A, Ouangre A, Cartoux M, Defer MC, Meda N, et al. Is sexually transmitted infection management among sex workers still able to mitigate the spread of HIV infection in West Africa? J Acquir Immune Defic Syndr. 2005;39(4):454-8.

28. Huet C, Ouedraogo A, Konaté I, Traore I, Rouet F, Kaboré A, et al. Longterm virological, immunological and mortality outcomes in a cohort of HIV-infected female sex workers treated with highly active antiretroviral therapy in Africa. BMC Public Health. 2011;11:700.

29. Nagot N, Ouangré A, Ouedraogo A, Cartoux M, Huygens P, Defer MC, et al. Spectrum of commercial sex activity in Burkina Faso: classification model and risk of exposure to HIV. J Acquir Immune Defic Syndr. 2002;29(5):517-21.

30. Kaufmann GR, Furrer $H$, Ledergerber B, Perrin L, Opravil M, Vernazza P, et al. Characteristics, determinants, and clinical relevance of CD4 T cell recovery to $<500$ cells/microL in HIV type 1-infected individuals receiving potent antiretroviral therapy. Clin Infect Dis. 2005:41(3):361-72.

31. Programme Sectoriel de lutte contre le SIDA et les IST. Normes et protocoles de prise en charge des personnes vivant avec le VIH au Burkina Faso. Ministère de la santé, Burkina Faso. 2014.

32. Rouet F, Ekouevi DK, Chaix ML, Burgard M, Inwoley A, Tony TD, et al. Transfer and evaluation of an automated, low-cost real-time reverse transcription-PCR test for diagnosis and monitoring of human immunodeficiency virus type 1 infection in a West African resource-limited setting. J Clin Microbiol. 2005;43(6):2709-17.

33. Aldrete S, Jang JH, Easley KA, Okulicz J, Dai T, Chen YN, et al. CD4 rate of increase is preferred to CD4 threshold for predicting outcomes among virologically suppressed HIV-infected adults on antiretroviral therapy. PLOS ONE. 2020;15(1):e0227124.

34. Morin M. L'observance aux traitements contre le VIH/sida. Mesure, déterminants, évolution. "Collection Sciences sociales et sida" ANRS, Paris. 2001.

35. Nakanjako D, Kiragga A, Ibrahim F, Castelnuovo B, Kamya MR, Easterbrook PJ. Sub-optimal CD4 reconstitution despite viral suppression in an urban cohort on antiretroviral therapy (ART) in sub-Saharan Africa: frequency and clinical significance. AIDS Res Ther. 2008;5:23.

36. Kroeze S, Ondoa P, Kityo CM, Siwale M, Akanmu S, Wellington M, et al. Suboptimal immune recovery during antiretroviral therapy with sustained HIV suppression in sub-Saharan Africa. AIDS. 2018;32(8):1043-51.

37. Moore RD, Keruly JC. CD4+ cell count 6 years after commencement of highly active antiretroviral therapy in persons with sustained virologic suppression. Clin Infect Dis. 2007;44(3):441-6.

38. Ledergerber B, Lundgren JD, Walker AS, Sabin C, Justice A, Reiss P, et al. Predictors of trend in CD4-positive T-cell count and mortality among HIV-1-infected individuals with virological failure to all three antiretroviraldrug classes. Lancet. 2004;364(9428):51-62.

39. Grønborg HL, Jespersen S, Hønge BL, Jensen-Fangel S, Wejse C. Review of cytomegalovirus coinfection in HIV-infected individuals in Africa. Rev Med Virol. 2017;27:1.

40. Matthews PC, Geretti AM, Goulder PJ, Klenerman P. Epidemiology and impact of HIV coinfection with hepatitis B and hepatitis C viruses in SubSaharan Africa. J Clin Virol. 2014;61(1):20-33.

41. Appay V, Fastenackels S, Katlama C, Ait-Mohand H, Schneider L, Guihot $A$, et al. Old age and anti-cytomegalovirus immunity are associated with altered T-cell reconstitution in HIV-1-infected patients. AIDS. 2011;25(15):1813-22.

42. van Griensven J, Phirum L, Choun K, Thai S, De Weggheleire A, Lynen L. Hepatitis B and C co-infection among HIV-infected adults while on antiretroviral treatment: long-term survival, CD4 cell count recovery and antiretroviral toxicity in Cambodia. PLoS ONE. 2014;9(2):e88552.

43. Cobos Jiménez V, Wit FW, Joerink M, Maurer I, Harskamp AM, Schouten J, et al. T-cell activation independently associates with immune senescence in HIV-infected recipients of long-term antiretroviral treatment. J Infect Dis. 2016;214(2):216-25

44. Viard J, Mocroft A, Chiesi A. Influence of age on CD4 cell recovery in HIVinfected patients receiving HAART: evidence from the EuroSIDA study. J Infect Dis. 2001;183(8):1290-4.

45. Teixeira L, Valdez H, McCune JM, Koup RA, Badley AD, Hellerstein MK, et al. Poor CD4 T cell restoration after suppression of HIV-1 replication may reflect lower thymic function. AIDS. 2001;15(14):1749-56. 
46. Gallant JE, DeJesus E, Arribas JR, Pozniak AL, Gazzard B, Campo RE, et al. Tenofovir DF, emtricitabine, and efavirenz vs. zidovudine, lamivudine, and efavirenz for HIV. N Engl J Med. 2006;354(3):251-60.

47. Huttner AC, Kaufmann GR, Battegay M, Weber R, Opravil M. Treatment initiation with zidovudine-containing potent antiretroviral therapy impairs CD4 cell count recovery but not clinical efficacy. AIDS. 2007;21(8):939-46.

48. Sloand EM, Kumar PN, Kim S, Chaudhuri A, Weichold FF, Young NS. Human immunodeficiency virus type 1 protease inhibitor modulates activation of peripheral blood CD4(+) T cells and decreases their susceptibility to apoptosis in vitro and in vivo. Blood. 1999;94(3):1021-7.

49. Abrogoua DP, Kablan BJ, Kamenan BA, Aulagner G, N'Guessan K, Zohoré C. Assessment of the impact of adherence and other predictors during HAART on various CD4 cell responses in resource-limited settings. Patient Prefer Adherence. 2012;6:227-37.

50. Gale HB, Gitterman SR, Hoffman HJ, Gordin FM, Benator DA, Labriola AM, et al. Is frequent CD4+T-lymphocyte count monitoring necessary for persons with counts $>=300$ cells/ $\mu \mathrm{L}$ and HIV-1 suppression? Clin Infect Dis. 2013;56(9):1340-3.

51. Girard PM, Nelson M, Mohammed P, Hill A, van Delft $Y$, Moecklinghoff $C$. Can we stop CD4+ testing in patients with HIV-1 RNA suppression on antiretroviral treatment? AIDS. 2013;27(17):2759-63.

52. Wade D, Daneau G, Aboud S, Vercauteren GH, Urassa WS, Kestens L. WHO multicenter evaluation of FACSCount CD4 and Pima CD4 T-cell count systems: instrument performance and misclassification of HIV-infected patients. J Acquired Immune Deficiency Syndr. 2014;66(5):e98.

\section{Publisher's Note}

Springer Nature remains neutral with regard to jurisdictional claims in published maps and institutional affiliations.

- fast, convenient online submission

- thorough peer review by experienced researchers in your field

- rapid publication on acceptance

- support for research data, including large and complex data types

- gold Open Access which fosters wider collaboration and increased citations

- maximum visibility for your research: over 100M website views per year

At BMC, research is always in progress.

Learn more biomedcentral.com/submissions 